longer approve the Minnitt apparatus for use by unsupervised midwives. This was only to be expected, though it is perhaps unfortunate that the reason given by the board for its decisior is the withdrawal by the British Oxygen Company of maintenance facilities. The same decision could have been more appropriately based on clinical considerations alone.

Thus the Minnitt era of obstetric analgesia with nitrous oxide and air comes to an end. Millions of mothers and innumerable midwives and doctors have good reason to be grateful to Dr. R. J. Minnitt, the distinguished Liverpool anaesthetist, for his energy and foresight in introducing this method. That his original mixture is now superseded by one thought to be safer is the inevitable result of advances in physics, engineering, and in the physiological and clinical outlook of anaesthetists and obstetricians. His outstanding contribution is not diminished thereby.

\section{Mental Illness and the Family Doctor}

The disproportion between the amount of mental illness in the population and the scanty resources devoted to its alleviation is striking. Sir Denis Hill, of the Maudsley Hospital, noted in a lecture a year" ago that " the vast load of neurotic suffering in the community" has received little recognition despite some special arrangements made for psychopaths, alcoholics, disturbed adolescents, and some other groups. But the bitter lesson is now being learnt, he believes, that for most categories of these sick people there are neither the financial resources nor the trained or interested personnel to fulfil the recommendations made in official reports. "Much has been recommended but little has or apparently can be done to implement them."

In the Rock Carling fellowship lecture, published in extended form as a monograph, ${ }^{2}$ Sir Denis returned to the theme this week. Despite a great expansion of the mental health services he considers their development lacks adequate planning or any general understanding of the roles of the people working in them. The great danger is that the individual needs of the patient will be overlooked. The objective of providing continuing care, he says, has been lost sight of in the conflict of opinion about the roles and responsibilities of the general practitioner, the hospital-based psychiatrist, and the local-authority social worker. In fact " administrative enthusiasm is in danger of supplanting good clinical judgement."

This criticism needs to be taken seriously. The admitted shortage of trained staff at all levels for coping with the mentally ill is defect enough in the health services without the added complication of confusic 1 over their functions. Yet there can hardly be any branch of medicine in which continuous care of the patient by staff who know his individual needs is more essential. Once again the role and training of the general practitioner come into question. So often and variously described as the backbone, linchpin, or keystone of our oddly constructed health service, family doctors must be tired of hearing how indispensable they are to undertaking work for which they have received so little training. According to Sir Denis Hill general practitioners attempt to help over $90 \%$ of the psychiatric sick who present to themperhaps two million patients a year in England and Wales.

1 Hill, Sir D., British Medical fournal, 1969, 1, 205.

- Hill, Sir D., Psychiatry in Medicine. London, Nuffield Provincial Hospitals Trust, 12s. 6d. net. 1969.
The mental states of these patients, numerous though they seem to be, may not represent any real increase of psychiatric illness in the population but simply be corning to the attention of the medical profession now. The result is an enormous demand by people for whom little provision has been made, and it is a demand on the caring professions, as Sir Denis puts it, which the present state of national finance and manpower could not hope to meet.

The general practitioner's continuing responsibility for his patients, a traditional role and one still acceptable today, should, in Sir Denis's view, be seen as the first priority, if for no other reason than its significance to the treatment of a vast amount of illness in the population-that is, mental and behavioural disorders. He reiterates what consultants in other branches of medicine have said in the past in the emphasis he places on the benefit that comes to patients from having a physician who knows their family and the background of their life. General practitioners would probably largely agree with him, but whether they find their training, despite improvements in recent years, properly fits them for the role in the management of the mentally sick is more questionable.

\section{Haemolysis in Hepatitis and Jaundice}

The idea that more than one system is affected in acute infectious hepatitis largely stems from detailed studies carried out by $M$. E. Conrad and his colleagues $^{12}$ on a group of American soldiers who developed the disease in Korea. In addition to changes in the mucosa of the small gut and in the kidney they found that the haemopoietic system was affected, which may be of more consequence. Rarely, a profound pancytopenia with marrow aplasia develops, ${ }^{3}$ or a severe haemolytic anaemia, which is sometimes associated with serum autoantibody. ${ }^{4}$ More commonly there is a transient depression of bone-marrow function with mild leucopenia, thrombocytopenia, and anaemia. A mild haemolysis contributes to the anaemia. In previous studies Conrad and his colleagues ${ }^{2}$ showed that $25 \%$ of the patients had a slightly shortened survival of erythrocytes during the acute stage of the illness, but the rate of haemolysis was insufficient to cause anaemia without a simultaneous decrease in production of these cells. Further evidence of a temporary depression of bone marrow-function was seen in the appearance of megaloblasts in about a third of the patients. ${ }^{2}$ Though the haemolysis enhances the hyperbilirubinaemia, it does not cause a reticulocytosis until the function of the bone marrow recovers.

In a recent paper Conrad ${ }^{-}$illustrates the findings in the "median patient" of the 68 cases of infectious hepatitis studied. A significant decrease in the packed cell volume (haematocrit value) was found for the first two weeks after admission, and then during the third and fourth week reticulocytosis was observed as the bone marrow recovered. This "median patient" had been ill for five days and jaundiced for one day before admission to hospital. $\mathrm{He}$ became asymptomatic during the second week in hospital, and laboratory tests returned to normal during the fourth week. But there were three patients in whom a compensated haemolytic state persisted for some years after recovery from the hepatitis. An indirect hyperbilirubinaemia and persistent reticulocytosis but with a normal haemoglobin level were found six months and one year after the onset of jaundice. \title{
.
}


Liver function tests were normal at these times, and a liver biopsy at one year showed normal histological appearances. In two patients, haemolysis was still detectable at two years, though in both the serum bilirubin and the reticulocyte count became normal during the third year. Studies carried out in these patients at one year after the onset of jaundice showed that the mechanism of the abnormal haemolysis was of an extracorpuscular nature. However, the exact cause was not found, and neither could Conrad explain why haemolysis persisted in only three of the 68 patients examined.

Increased haemolysis has been described in other forms of liver disease. Indeed, Banti in $1894^{6}$ drew attention to an extension of the red marrow into the shaft of the femur in cases of cirrhosis with splenomegaly. Sequestration and destruction of red cells in an enlarged spleen can certainly account for some instances of haemolytic anaemia in association with cirrhosis, and the indirect hyperbilirubinaemia and haemolysis that sometimes develop after a portacaval anastomosis are cured by splenectomy. ${ }^{7}$ But in most cases of cirrhosis this is not the explanation. C. S. Pitcher and R. Williams ${ }^{8}$ found a reduced survival time for red cells not only in cirrhosis but also in obstructive jaundice, whether of intra- or extrahepatic type. Cross-transfusion studies, as in Conrad's patients with infectious hepatitis, suggested an extracorpuscular mechanism, probably due to a plasma factor. They showed further that when labelled red cells from a patient with obstructive jaundice were transfused into a normal person the rate of disappearance was as rapid as that previously observed in the patient. This suggests that the red cells, as a result of the extracorpuscular factor, had acquired an intrinsic and apparently irreversible defect. No evidence of a direct lytic effect from jaundiced plasma was found, and the reduction in red-cell survival could not be correlated with morphological changes in the red cells, such as target cell or macrocyte formation. Levels of reduced glutathione in the red cell were low in many of the patients, and in some of them the reduced glutathione showed increased instability. However, in contrast to the situation in congenital haemolytic anaemia due to glucose-6-phosphate dehydrogenase deficiency, this enzyme and others concerned in the maintenance of reduced glutathione were found to be normal in the cirrhotic patients. These changes in glutathione metabolism have been confirmed by two other groups of workers. ${ }^{910}$

A similar reduction in red-cell survival has also been found in about half the patients with Gilbert's disease examined. ${ }^{11}$ In this variety of congenital unconjugated hyperbilirubinaemia the primary defect may be in the uptake of bilirubin into the cell, ${ }^{12}$ though recently a reduction of the activity

1 Conrad, M. E., Schwartz, F. D., and Young, A. A., American fournal

${ }^{2}$ Conrad, M. E., Weintraub, L. R., Schwartz, F. D., and Young, A. A., Progress in Liver Disease, ed. H. Popper and F. Schaffner, 1965, Progress in Liver Disease, ed. H. Popper
Vol. 2, p. 395 . London, Heinemann.

3 Rubin, E., Gottlieb, C., and Vogel, P., American fournal of Medicine,

1 Dacie, J. V., in The Haemolytic Anaemias, 1967, Part 3, p. 835. London, Churchill.

b Conrad, M. E., Gut, 1969, 10, 516.

Banti, G., Semaine Médicale, 1894, 14, 318.

Da Silva, L. C., et al., Gastroenterology, 1963, 44, 117.

8 Pitcher, C. S., and Williams, R., Clinical Science, 1963, 24, 239.

Boivin, P., Haguenau, F., Galand, C., and Fauvert, R., Nouvelle Revue Française d'Hématologie, 1964,' 4, 712.

10 Sirchia, G., Ferrone, S., and Crosti, P., Lancet, 1966, 2, 1363.

1 Powell, L. W., Billing, B. H., and Williams, H. S., Australasian Annals of Medicine, 1967, 16, 221 .

2 Billing, B. H., Williams, R., and Richards, T. G., Clinical Science, 1964, 27, 245.

${ }^{3}$ Black, M., and Billing, B. H., New England fournal of Medicine,

$1969,280,1266$.
14 Powell, L. W., Dunnicliff, M. A., and Billing, B. H., British fournal of Haematology, 1968, 15, 429. of the hepatic enzyme glucuronyl-transferase, responsible for the conjugation of bilirubin prior to excretion, has been described. ${ }^{13}$ The occurrence of a reduction in red-cell survival in Gilbert's disease may make difficult its differential diagnosis from a persisting unconjugated hyperbilirubinaemia and haemolysis following infectious hepatitis, particularly since patients with Gilbert's disease often present to the doctor during the course of an unrelated infection, when jaundice becomes evident and the patient may have symptoms of nausea and abdominal pain.

The decrease in red-cell survival in Gilbert's disease is also of interest because it has been suggested that the haemolysis found is due to retention of bile salts in the blood, as in the various types of liver disease mentioned. However, L. W. Powell and his colleagues ${ }^{14}$ showed by experiments on rats that the haemolytic process accompanying obstructive jaundice may be related to the increased levels of conjugated bilirubin in the plasma but not to the accumulation of conjugated bile acids, phospholipids, and cholesterol. An increase in circulating unconjugated bilirubin is not necessarily associated with haemolysis. The reduction in red-cell survival in some patients with Gilbert's disease is therefore also unexplained.

Thus many loose ends remain to be tied up, and perhaps more attention should be paid to the biochemical disturbances induced in the red cell in these different types of jaundice and liver damage.

\section{Christmas Offerings}

Giving the general public the latest news of doctors and their doings is one of the more remarkable growth industries of our time. But the fact that most people would rather be shocked than instructed is an aspect of human nature that has worried moralists through the ages. Never more public than at Tyburn a few generations back, the same proclivity is more privately catered for today by surgical operations on television, bringing into the home their message of healing through injury.

But helping the general public understand the art of healthy living is a task many doctors take seriously, and it is gratifying to note that a number of public lectures to that end are being arranged for young people during the Christmas holiday. Helpfully publicized last week in The Times, ${ }^{1}$ the lectures are to be held at the Royal Colleges of Physicians and Surgeons in London and the Royal Society of Medicine. They include talks on air pollution, exercise and heart disease, hazards of the sea, and medical work in the South American jungle.

There is a case for giving more lectures of this kind to schoolchildren on the varieties of medical experience, for medicine remains one of the most worthwhile occupations with which to stir any young person's imagination. Nor should they be denied advice on some of the threats to health with which they are likely to be tempted. Tobacco smoking is an obvious theme. The eating of sweets in excess is another, for Britain is said to have the highest consumption of them per head of population in the world. Also of prime importance today is the illicit taking of drugs. But the difficulty is to find lecturers who can spare the time, win the confidence of a young audience, and give easily memorable guidance that neither exaggerates nor minimizes the dangers. These Christmas offerings certainly deserve encouragement.

1 Keenan, M., The Times, 3 December 1969. 